\title{
Manifestasi klinis tipe kandidiasis oral pada penderita AIDS di Rumah Sakit Dr Wahidin Sudirohusodo, Makassar (Clinical manifestations of oral candidiasis types in AIDS patients at Dr Wahidin Sudirohusodo Hospital, Makassar)
}

\author{
${ }^{1}$ Sumintarti, ${ }^{2}$ Andi Rasdiana $S$ \\ ${ }^{1}$ Bagian Ilmu Penyakit Mulut \\ ${ }^{2}$ Mahasiswa tahap profesi \\ Fakultas Kedokteran Gigi Universitas Hasanuddin \\ Makassar, Indonesia
}

\begin{abstract}
Oral candidiasis is one of clinical manifestations in aquired immune deficiency syndrome (AIDS) patients. This condition is a common opportunistic infection of the oral cavity caused by an overgrowth of Candida spesies. The clinical types of oral candidiasis are erythematous or atropic, pseudomembranous, hyperplastic or chronic, and angular cheilitis. AIDS is group of symptoms that resulting from infection of human immunodeficiency virus (HIV). This case is associated with the decreasing of CD4 count. The aim of this study was to know the types of oral candidiasis on AIDS patients at Dr Wahidin Sudirohusodo Hospital. This observational study with a cross-sectional design examined 30 patients with AIDS who suffered from oral candidiasis, to determine its type after the diagnosis had confirmed by culture test. Their CD4 cell count taken from their medical records. The result showed that Pseudomembranous candidiasis were found to be higher (76.7\%), that was followed by angular cheilitis (23.3\%), hyperplastic (16.7\%), and erythematous (6.7\%). They were showed showed CD4 T cell count $<200$ cells $/ \mathrm{mm}^{3}$ (63.3\%). From this study, it was concluded that pseudomembranous candidiasis is the most common type and showed that CD4 T cell count $<200 \mathrm{cell} / \mathrm{s} / \mathrm{mm}^{3}$ was found to be most common from the AIDS patients.
\end{abstract}

Keywords: HIV, AIDS, Oral Candidiasis, CD4 T Cell

\begin{abstract}
ABSTRAK
Kandidiasis oral adalah salah satu manifestasi pada penderita acquired immune deficiency syndrome (AIDS). Kondisi ini merupakan infeksi oportunistik pada rongga mulut yang disebabkan oleh pertumbuhan Candida. Gambaran klinis kandidiasis oral terdiri atas kandidiasis eritematos atau atropik, kandidiasis pseudomembran, kandidiasis hiperplastik atau kronis, dan angular cheilitis. AIDS merupakan kumpulan gejala penyakit yang disebabkan oleh human immunodeficiency virus (HIV). Hal ini berhubungan dengan penurunan jumlah CD4. Penelitian ini dilakukan untuk mengetahui tipe kandidiasis oral yang ditemukan pada penderita AIDS di Rumah Sakit Dr Wahidin Sudirohusodo, Makassar. Pada penelitian observasi analitik dengan desain cross-sectional study, dilakukan pemeriksaan terhadap 30 pasien AIDS yang menderita kandidiasis oral untuk menentukan tipenya, setelah diagnosis diketahui melalui tes kultur. Jumlah sel T CD4 pasien didapatkan dari rekam medik pasien. Hasil penelitian ini menunjukkan bahwa kandidiasis pseudomembran merupakan tipe terbanyak yang ditemukan (76,7\%), kemudian diikuti angular cheilitis sebanyak 23,3\%, kemudian tipe kandidiasis hiperplastik (16,7\%), serta kandidiasis eritematous sebanyak 6,7\%. Pada 30 penderita AIDS dengan kandidiasis oral didapatkan jumlah sel T CD4 $<200 \mathrm{sel} / \mathrm{mm}^{3}$ dengan jumlah terbanyak yakni 63,3\%. Dari penelitian ini didapatkan seluruh tipe kandidiasis oral; kandidiasis pseudomembran merupakan tipe yang paling umum terjadi. Penderita AIDS dengan kandidiasis oral lebih banyak didapatkan memiliki jumlah sel T CD4 $<200 \mathrm{sel} / \mathrm{mm}^{3}$.

Kata kunci: HIV, AIDS, kandidiasis oral, sel T CD4
\end{abstract}

Koresponden: Sumintarti, E-mail: miensugiharto@yahoo.co.id

\section{PENDAHULUAN}

Acquired immune deficiency syndrome (AIDS) adalah kumpulan gejala atau infeksi yang disebabkan oleh human immunodeficiency virus (HIV). Human immunodeficiency virus menyerang sistemkekebalan tubuh sehingga menyebabkan penurunan daya tahan tubuh penderita. Pada penderita AIDS, penurunan kemampuan sistem kekebalan tubuh berkaitan erat dengan tingkat kejadian infeksi oportunistik. Secara kumulatif kasus AIDS di Indonesia sejak tanggal 1 April 1987 hingga 31 Desember 2011 jumlahnya sebanyak 29.879 dengan angka kematian sebanyak 5.430 jiwa. Pada penderita AIDS berdasarkan jenis kelamin terbanyak adalah laki-laki dengan 20.333 kasus sedangkan perempuan hanya 8.122 kasus. ${ }^{1}$

Angka morbiditas dan angka mortalitas yang disebabkan oleh infeksi HIV semakin meningkat dan merupakan masalah kesehatan masyarakat menjadi perhatian diseluruh dunia. Hingga saat ini belum juga ditemukan imunisasi profilaksis ataupun pengobatan AIDS. Meskipun demikian model terapi antiretrovirus sepertihighly active anteretroviral theraphy (HAART) tetap dikembangkan. ${ }^{2}$

Kesehatan rongga mulut merupakan komponen yang penting dalam menilai status kesehatan secara keseluruhan pada penderita AIDS. Peranan dokter 
gigi dalam membantu mendiagnosis penyakit AIDS adalah sangat penting, karena manifestasi di mulut dapat merupakan tanda awal dari infeksi HIV seperti pada banyak penyakit sistemik lainnya. ${ }^{3}$

Lesi rongga mulut yang berkaitan dengan AIDS yang paling umum ditemukan adalah kandidiasis oral. Kandidiasis oral disebabkan oleh pertumbuhan jamur Candida, yang umumnya Candida albicans, meskipun demikian spesies Candida non-albicans juga ditemukan. Berdasarkan gambaran klinisnya, kandidiasis oral dibedakan menjadi 4 jenis, yaitu kandidiasis eritematous atau atropik, kandidiasis pseudomembran, kandidiasis hiperplastik atau kronis, dan angular cheilitis. ${ }^{4}$

Perawatan dari kandidiasis oral tergantung dari tipe kandidiasis, distribusi, dan tingkatan keparahan infeksi. Peranan dokter gigi dalam masalah yang berhubungan dengan AIDS sangat penting karena. dokter gigi juga dituntut memiliki kemampuan dalam mengenal adanya infeksi HIV, dan berbagai tandatanda serta dampaknya pada rongga mulut, seperti terjadinya kandidiasis oral yang merupakan infeksi oportunistik dari AIDS. ${ }^{3}$

Berdasar latar belakang permasalahan tersebut, pada artikel ini dibahas mengenaitipe kandidiasis oral pada penderita AIDS di Rumah Sakit Dr Wahidin Sudirohusodo, Makassar.

\section{BAHAN DAN METODE}

Jenis penelitian ini adalah observasi analitik yang menggunakan rancangan penelitian crosssectional dengan melakukan pemeriksaan rongga mulut penderita AIDS yang menderita kandidiasis oral. Pengambilan sampel lesi kandidiasis oral pada penderita AIDS dilakukan dengan metode hapusan menggunakan cotton swab. Sesudah pengambilan hapusan kandidiasis, dilakukan pemeriksaan kultur di laboratorium.
Dengan cara purposive sampling, diperoleh 30 sampel penderita AIDS yang menderita kandidiasis oral dengan kriteria inklusi sampel penelitian, yakni penderita AIDS yang dirawat di Rumah Sakit Dr Wahidin Sudirohusodo Makassar.

\section{HASIL}

Beberapa penelitian ilmiah membuktikan bahwa insidensi lesi rongga mulut pada penderita AIDS terus meningkat. Lesi rongga mulut yang paling umum adalah kandidiasis oral dan hal ini berkaitan dengan penurunanjumlah selT CD4. Adanya hubungan yang begitu erat antara terjadinya lesi rongga mulut dan perkembangan AIDS, maka sering dilakukan riset mengenai infeksi HIV atau AIDS dan perluasannya. ${ }^{5}$

Adapun dalam penelitian ini dibahas mengenai beberapa hal yang terkait dengan manifestasi klinis kandidiasis oral pada penderita AIDS ditinjau dari jenis kelamin, jumlah sel T CD4, kelompok umur, tipe Candida dan tipe kandidiasis yang terlihat pada tabel 1. Ditunjukkan bahwa distribusi karakteristik responden berdasarkan jenis kelamin, yakni 11 perempuan $(36,7 \%)$ dan 19 laki-laki orang $(63,3 \%)$. Berdasarkan kelompok jumlah sel T CD4 $>200 / \mathrm{mm}^{3}$ sebanyak 1 orang $(3,3 \%)$, jumlah sel T CD4 $<200$ sebanyak 19 orang $(63,3 \%)$ dan yang tidak diketahui jumlah sel T CD4 sebanyak 10 orang (3,3\%).

Berdasarkan kelompok umur ditemukan 2 orang $(6,7 \%)$ pada kelompok umur 0-4 tahun, kelompok umur 5-19 tahun sebanyak 3 orang (10\%), kelompok umur 20-29 tahun sebanyak 9 orang (30\%), kelompok umur 30-39 tahun sebanyak 11 orang atau 36,7\%, kelompok umur $40-49$ tahun sebanyak 2 orang $(6,7 \%)$ dan kelompok umur 50-59 tahun 3 orang (10\%).

Adapun berdasarkan pemeriksaan laboratorium juga ditemukan beberapa tipe Candida, yaitu Candida albicans pada 15 orang (50\%), C.pseudotropikalis pada 6 orang $(20 \%)$ dan C.kruseipada 9 orang $(30 \%)$.

Tabel 1 Distribusi karakteristik responden

\begin{tabular}{clcc}
\hline & Variabel & Frekuensi & $\%$ \\
\hline \multirow{3}{*}{ Jenis Kelamin } & 19 & 63,3 \\
& Laki-Laki & 11 & 36,7 \\
\hline \multirow{3}{*}{ Jumlah sel T CD4 } & Perempuan & 1 & 3,3 \\
& $>200 / \mathrm{mm}^{3}$ & 19 & 63,3 \\
& $<200 / \mathrm{mm}^{3}$ & 10 & 33,3 \\
\hline \multirow{5}{*}{ Umur } & Tidak tahu & 2 & 6,7 \\
& 0-4 Tahun & 3 & 10,0 \\
& 5-19 Tahun & 9 & 30,0 \\
& 20-29 Tahun & 11 & 36,7 \\
& 30-39 Tahun & 2 & 6,7 \\
& 40-49 Tahun & 3 & 10,0 \\
\hline \multirow{5}{*}{ Tipe Candida } & 50-59 Tahun & 15 & 50,0 \\
& C. Albicans & 6 & 20,0 \\
& C.Pseudotropikalis & 9 & 30,0 \\
& C. Krusei & $\mathbf{3 0}$ & $\mathbf{1 0 0}$ \\
\hline
\end{tabular}


Tabel 2 Distribusi jawaban responden berdasarkan tipe kandidiasis

\begin{tabular}{cccc}
\hline Tipe kandidiasis & Jawaban & Frekuensi & $\%$ \\
\hline \multirow{2}{*}{ Pseudomembran } & Ya & 23 & 76,7 \\
& tidak & 7 & 23,3 \\
\hline \multirow{2}{*}{ Eritematous } & Ya & 2 & 6,7 \\
& Tidak & 28 & 93,3 \\
\hline \multirow{2}{*}{ Hiperplastik } & Ya & 5 & 16,7 \\
& Tidak & 25 & 83,3 \\
\hline \multirow{2}{*}{ Angular Cheilitis } & Ya & 7 & 23,3 \\
& Tidak & 23 & 76,7 \\
\hline
\end{tabular}

Berdasarkan jenisnya, diketahui tipe kandidiasis pseudomembran sebanyak 23 orang $(76,7 \%)$, tipe kandidiasis eritematous sebanyak 2 orang $(6,7 \%)$, kandidiasis hiperplastik sebanyak 5 orang $(16,7 \%)$ dan angular cheilitis sebanyak 7 orang $(23,3 \%)$. Terdapat 6 orang penderita AIDS yang mengalami 2 manifestasi kandidiasis sekaligus yaitu kandidasis pseudomembran dan angular cheilitis, dan terdapat seorang penderita yang mengalami dua manifestasi kandidiasis sekaligus yaitu terjadi hiperplastik dan angular cheilitis, sehingga jumlah manifestasi yang ditemukan adalah 37 kasus.

\section{PEMBAHASAN}

Kandidiasis oral merupakan infeksi oportunistik yang paling umum terjadi pada penderita AIDS, yang disebabkan karena pertumbuhan spesies Candida, khususnya Candida albicans. Hal tersebut dikaitkan dengan menurunnya jumlah sel T CD4. Pemeriksaan pada setiap pasien dilakukan untuk menentukan tipe kandidiasis oral.

Dari hasil penelitian ini didapatkan jumlah lakilaki yang menderita kandidiasis oral $(63,3 \%)$ dan perempuan $(36,7 \%)$. Hal ini sesuai dengan data hasil penelitian Aptriani dkk yang menunjukkan bahwa penderita AIDS yang tercatat di klinik VCT RSUD Arifin Achmad lebih banyak laki-laki yaitu dengan jumlah 56 orang $(63,64 \%)$ dan perempuan dengan jumlah 32 orang $(36,36 \%)$. Hal ini disebabkan lakilaki umumnya mempunyai mobilitas tinggi, suka berganti pasangan, dan cenderung untuk memakai NAPZA dengan jarum suntik. ${ }^{6}$

Cukup tingginya perbedaan proporsi kasus AIDS pada laki-laki dan perempuan dikarenakan mayoritas penggunajarum suntikialahlaki-laki.Demikian pula dengan pelanggan seks komersial kebanyakan ialah laki-laki. ${ }^{1}$

Berdasarkan kelompok umur, ditemukan paling banyak pada kelompok umur 30-39 tahun sebanyak 11 orang $(36,7 \%)$, diikuti kelompok umur 20-29 tahun sebanyak 9 orang $(30 \%)$. Hal ini sesuai dengan riset oleh Innes yang dilakukan di RSUP Dr. Kariadi Semarang terhadap 42 pasien HIV/AIDS, yang mendapatkan hasil bahwa jumlah terbanyak pasien HIV/AIDS yaitu pada kelompok umur 30-39 tahun sebanyak 17 orang $(40,48 \%)$ dan kelompok umur 20-29 tahun sebanyak 13 orang (30,95\%). Hal ini karena pada kelompok usia produktif ini merupakan usia seseorang sedang aktif melakukan hubungan seksual dan penyalahgunaan obat yang merupakan risiko tinggi untuk tertularnya $\mathrm{HIV}$.

Selain itu, penelitian Simanjuntak menunjukkan adanya hubungan yang signifikan antara umur dan HIV/AIDS; disimpulkan bahwa umur yang paling berisiko terhadap HIV/AIDS adalah usia25-34 tahun, umur 15-24 tahun dan umur 35-44 tahun. Kelompok usia tersebut masuk dalam kategori usia remaja dan usia produktif, yang sangat berisiko tertular HIV dan AIDS. Infeksi HIV sebagian besar (80\%) diderita oleh kelompok usia produktif(15-49 tahun). Remaja sangat rentan dengan HIV/AIDS, oleh karena usia remaja identik dengan semangat bergelora dan terjadi peningkatan libido. Selain itu risiko ini disebabkan faktor lingkungan dari remaja tersebut. ${ }^{8}$

Berdasarkan jumlah sel T CD4, diketahui jumlah sel TCD4 $<200 / \mathrm{mm}^{3}$ sebanyak 19 orang $(63,3 \%)$ dan jumlah sel T CD4 $>200$ sebanyak 1 orang $(3,3 \%)$. Hal ini sesuai dengan penelitian yang dilakukan Innes di RSUP Dr.Kariadi Semarang bahwa dari 42 pasien HIV/AIDS yang dirawat di bangsal penyakit dalam, sebesar $90,47 \%$ pasien memiliki jumlah sel T CD4 $<200 \mathrm{sel} / \mathrm{mm}^{3}$.

Hasilpenelitian oleh Aptrini juga menunjukkan bahwa dari 88 data rekam medik pasien HIV/AIDS yang tercatat diklinik VCT RSUD Arifin Achmad, jumlahselT CD4 pasien HIV/AIDS terbanyak adalah pada jumlah sel T CD4 $<200 \mathrm{sel} / \mathrm{mm}^{3}$ sebanyak 64 orang $(72,73 \%)$. Dari penelitian lain juga didapatkan penderita HIV/AIDS tertinggi adalah pada jumlah selTCD $4<200 \mathrm{sel} / \mathrm{mm}^{3}$ sebanyak 180 orang $(80,7 \%)$. Tingginya jumlah penderita dengan jumlah sel $\mathrm{T}$ CD4 $<200 \mathrm{sel} / \mathrm{mm}^{3}$ diakibatkan karena penderita memeriksakan dirinya ketika sudah muncul infeksi oportunistik, padahal pada saat ini imunitas sudah menurun yang ditandai dengan jumlah sel T CD4 di bawah normal. $^{6}$

Berdasarkan tipe kandidiasis oral yang diperoleh, kandidiasis pseudomembran merupakan tipe paling umum yaitu 76,7\%, kemudian diikuti angular cheilitis sebanyak 23,3\%, lalu tipe kandidiasis hiperplastik $(16,7 \%)$ dan kandidiasis eritematous sebanyak $6,7 \%$. Hal ini tidak sesuai dengan hasil penelitian Ashish dkk bahwa jenis kandidiasis yang paling banyak ditemukan pada pasien terinfeksi HIV adalah tipe eritematous dengan jumlah 122 penderita $(30,6 \%)$, diikuti kandidiasis pseudomembran sebanyak 49 orang $(12,3 \%)$ dan angular cheilitis 17 orang $(4,3 \%) .{ }^{9}$ 
Beberapa penelitian lain juga menyatakan bahwa tipe kandidiasis yang paling umum ditemukan adalah tipe kandidiasis pseudomembran akut dan kandidiasis eritematous; yakni kandidiasis pseudomembran lebih berhubungan dengan penurunan jumlah sel T CD4 $<200 / \mathrm{mm}^{3}$. Pada penelitian Shetti dkk dijelaskan bahwa pada penderita AIDS, kandidiasis oral tipe pseudomembran adalah jenis yang paling umum ditemukan. Sementara pada pasien yang terinfeksi HIV, kandidiasis eritematous yang paling umum ditemukan. $^{10}$

Hasil pemeriksaan laboratorium ditemukan tipe Candida, yakni C.albicans dengan jumlah terbanyak yakni (50\%), C.krusei (30\%), C.pseudotropicalis $(20 \%)$. Hal ini sesuai dengan penelitian Okonkwo $\mathrm{dkk}$, mengenai prevalensi Candida yang didapatkan pada penderita HIV di Nigeria, yakni ditemukan 30 Candida, yakni 24 (80\%) C.albicans. Selain itu juga didapatkan tipe Candida non albicans, yakni $C$. tropicalis 1(3,33\%), C.pseudotropicalis 3 (10\%), C. parasiolosis dan C.guilliermondii masing-masing 1 $(3,33 \%){ }^{11}$

Hasil tersebut didukung penelitian yang dilakukan oleh Khan dkk yang menyatakan bahwa tipe Candida yang didapatkan dengan melakukan hapusan pada rongga mulut pada daerah kandidiasis terbanyak adalah C.albicans yaitu sebanyak 41 , yang diikuti oleh C.guillermondi sebanyak 12. Penelitian lainjuga mendapatkan distribusi Candida yang diisolasi dari hapusan rongga mulut pasien terinfeksi HIV/AIDS menunjukkan hasil yang sama yakni C.albicans ditemukan sebanyak 52\% dan selebihnya Candidanon albicans. ${ }^{12}$

Dari hasil penelitian yang dilakukan di Rumah Sakit Dr Wahidin Sudirohusodo disimpulkan adanya semua jenis kandidiasis oral, yaitu tipe kandidiasis pseudomembran, kandidiasis eritematous, angular cheilitis, kandidiasis hiperplastik. Tipe kandidiasis pseudomembran akut merupakan tipe paling umum yang ditemukan yakni sebanyak 23 (76,7\%).

\section{DAFTAR PUSTAKA}

1. Kalalo JGK, Tjitrosantoso H, Lily G. Studi penatalaksanaan terapi pada penderita HIV/AIDS di klinik VCT rumah sakit kota Manado. J Farmasi Univ Sam Ratulangi 2012;2:100

2. Donel S, Savira M, Krisnadi S. Pencegahan dan penalaksanaan infeksi HIV/AIDS pada kehamilan. J Kedokteran 2010;7

3. Rachimhadhi T. Sindroma AIDS: penanggulangan penyebarannya dalam praktek dokter gigi. Jakarta: EGC; 1992. h. 28-32

4. Bajpai S, Paazare AR. Oral manifestaion of HIV. Contemp Clint Dent J 2007;1:3

5. Greenspan JS. The mouth as a window on HIV Infection. J Sci Comm 2000;4:2

6. Aptrini R, Fridayenti, Barus A. Gambaran jumlah CD4 pada pasien HIV/AIDS di klinik VCT RSUD Arifin Achmad Provinsi Riau periode Januari-Desember 2013. J Jom FK 2014;1:2-9

7. Innes A. Karakteristik pasien HIV/AIDS dengan kandidiasis orofaringeal di RSUP Dr Kariadi Semarang. Fakultas Kedokteran Universitas Diponegoro 2011

8. Simanjuntak E. Analisis faktor resiko penularan HIV/AIDS di kota Medan. J Pembangunan Manusia 2010; 4: 4

9. Ashish B, Sindhu M, Ganvir, Vinay K, Hazarey. Oral manifestations of HIV infection and their correlation with CD4 count. J Oral Sci 2011; 53: 206

10. Shetti A, Gupta I, Shivyogi. Oral candidiasis: Aiding in the diagnois of HIV-a case report. J Hindawi Publishing Corporation 2011; 2

11. Okonkwo, Alo M, Nworie O, Orji J. Agah M. Prevalence of oral Candida albicans infection in HIV sero-positive patients in abakaliki. Am J Life Sci 2013;2:73

12. Khan A, Malik A, Khan S. Profile of candidiasis in HIV infected patients. Iranian J Microbiol 2012;4:207 